\title{
Protein NDRG1
}

National Cancer Institute

\section{Source}

National Cancer Institute. Protein NDRG1. NCI Thesaurus. Code C33965.

Protein NDRG1 (394 aa, 43 kDa) is encoded by the human NDRG1 gene. This protein may play a role in the cellular response to chemical stress. 